\title{
SUBJEKTYVIŲ IR OBJEKTYVIŲ MOTERS ODOS BŪKLE்S RODIKLIŲ POKYČIAI MENSTRUACINIO CIKLO METU
}

\author{
Austėja Vaitkūnaitė, Žaneta Mickienė, Jolanta Juozapavičienė, Sandrija Čapkauskienė \\ Kauno kolegijos Medicinos fakultetas
}

Raktažodžiai: subjektyvūs odos rodikliai, objektyvūs odos rodikliai, moterys, menstruacinis ciklas.

\begin{abstract}
Santrauka
Menstruacinio ciklo metu kiekviena sveika vaisingo amžiaus moteris patiria ciklinius fiziologinius pokyčius. Dėl kintančių hormonų koncentracijos kraujyje, pastebimi tam tikri ịvairių audinių bei organų, taip pat ir odos būklès, pokyčiai. Kinta odos riebumas, jautrumas, tankumas bei daugelis kitų rodiklių. Kintant moterų gyvenimo būdui ir sąlygoms, keičiantis visuomenès socialinėms normoms, ankstejant menarchei, moterys vis didesnę dalị savo gyvenimo patiria menstruacijas bei su jomis susijusius organų ir funkcijų, tarp jų ir odos, pokyčius, todèl kosmetologui, norinčiam užsitikrinti profesinę sèkmę, būtina gilintis ị šių pokyčių dinamiką. Šio tyrimo tikslas - iqvertinti subjektyvius ir objektyvius odos būklès rodiklių pokyčius moters menstruacinio ciklo metu. Kintant hormonų, ypač estrogeno, koncentracijai, moters menstruacinio ciklo metu pastebimi ịvairūs odos būklès pokyčiai: kinta jautrumas, riebumas, drègmė, spalva ir kt. Tyrimo metu labiausiai išryškejjo U zonos riebumo padidejjimas 34-45 metų amžiaus grupejje. Subjektyvūs odos būklès rodikliai taip pat ženkliai pakito abiejose amžiaus grupèse.
\end{abstract}

\section{Ivadas}

Menstruacinis ciklas - tai sveikų, lytiškai subrendusių moterų reguliariai patiriami organizmo pokyčiai [1]. Cikliniai hormonų pokyčiai, kurie reguliuoja moterų menstruacini ciklą, turi didelę moters kūnui įtaką, pasireiškiančią tiek fiziniais, tiek emociniais pokyčiais. Menstruacinį ciklą kontroliuoja tiksliai sureguliuoti estrogeno ir progesterono koncentracijų pokyčiai organizme, kurie sukelia ịvairių audinių ir organų pokyčius [2]. Oda, didžiausias žmogaus kūno organas, dermoje ir epidermyje turi gausybę estrogenui ir šiek tiek mažiau - progesteronui jautrių receptoriu [3]. Ji dengia visą kūno išorinị paviršių, saugodama jị nuo patogenų, UV spinduliuotès, cheminių medžiagų, teikia mechaninę apsaugą, atlieka termoreguliacinę funkciją, dalyvauja vandens apykaitoje. Odoje gaminasi ịvairios organizmui reikalingos medžiagos [4]. Cikliškai kintantys estrogeno ir progesterono kiekiai veikia daugelị odos struktūrų bei funkcijų, pradedant nuo epiderminių lipidų produkcijos ir riebumo išskyrimo pokyčių, odos tankumo, riebalų pasiskirstymo iki odos drègmès bei apsauginès funkcijos. Kinta odos pigmentacija ir tikimybè būti pažeistai UV spindulių, vyksta pokyčiai odos mikrofloroje. Kintantys hormonų kiekiai menstruacinio ciklo metu ịvairiai veikia imunitetą bei tikimybę paūmèti ivvairioms ligoms [5]. Menarchè - svarbi data moters gyvenime. Nesvarbu, kiek moteriai metų, ji visada prisimins pirmąsias menstruacijas [6]. Kintant gyvenimo sąlygoms, menarchè pasireiškia vis anksčiau, moterys vidutiniškai turi mažiau vaikų, ilgèja gyvenimo trukmè, laikotarpis, per kurị moterys patiria menstruacijas, yra vis ilgesnis, todèl ilgèja ir cikliškai patiriamų pokyčių moterų odoje laikotarpis $[7,8]$. Atsižvelgiant ị tai, būtina geriau ịsigilinti ị su menstruaciniu ciklu susijusius pokyčius moterų organizme. Išskiriamos trys menstruacinio ciklo fazès: folikulinè, menstruacinè ir liuteininè. Šių fazių metu išskiriami hormonai pasižymi metaboliniu ir morfogeniniu veikimu. Veikdami metaboliškai, jie reguliuoja medžiagų, vandens ir elektrolitų apykaitą, didina ląstelès membranų laidumą, medžiagų transportą, fermentų aktyvumą, o veikdami morfogeniškai - reguliuoja reprodukcinę funkciją, audinių diferenciaciją, formą, augimą [9].

Tyrimo tikslas - nustatyti subjektyvius ir objektyvius odos būklès rodiklių pokyčius moters menstruacinio ciklo metu.

\section{Tyrimo objektas ir metodika}

Tyrime dalyvavo 8 moterys: po 4 18-25 ir 34 - 45 metu amžiaus grupèse. Tyrimo dalyvès naudojo ịprastines odos priežiūros priemones, nesilankè soliariume, nesidegino saulèje, nepakeite ịprastos gyvensenos, nenaudojo hormoninès kontracepcijos priemonių. Tiriamujų odos tipas - riebi oda. Odos būklès rodikliai vertinti diagnostikos aparatais „Dermoprime“ ir „Soft Plius“. Kiekvienai tyrimo dalyvei 
matavimai buvo atliekami du kartus: menstruacinio ciklo viduryje ir po dviejų savaičių - vèlyvojoje liuteininèje fazèje, prieš pat prasidedant menstruacijoms. Buvo išmatuoti šie objektyvūs odos rodikliai: riebumas (vertinti $\mathrm{T}$ ir $\mathrm{U}$ veido zonose), drègmè ir keratino kiekis. Subjektyvūs odos rodikliai -jautrumas, šerpetojimas, riebalavimasis, tempimo jausmas bei jų pokyčiai buvo nustatyti užduodant specialius klausimus. Šie klausimai kiekvienai tyrimo dalyvei buvo pateikti menstruacinio ciklo viduryje ir po dviejų savaičių vèlyvojoje liuteininèje fazèje (kiekvieną kartą po objektyvių odos būklès parametrų matavimo diagnostikos aparatūra). Subjektyvius rodiklius respondentès vertino balu skalèje nuo 0 iki 4.0 - nèra pojūčių, 1 - neryškūs, 2 - vidutiniški (kartais pasireiškia, kartais ne), 3 - ryškūs, 4 - labai ryškūs.

\section{Tyrimo rezultatai}

18-25 metų amžiaus grupejje stebimi reikšmingi pokyčiai visų tirtų rodiklių rodmenyse $(p<0,05)$. Riebumas $T$ bei $U$

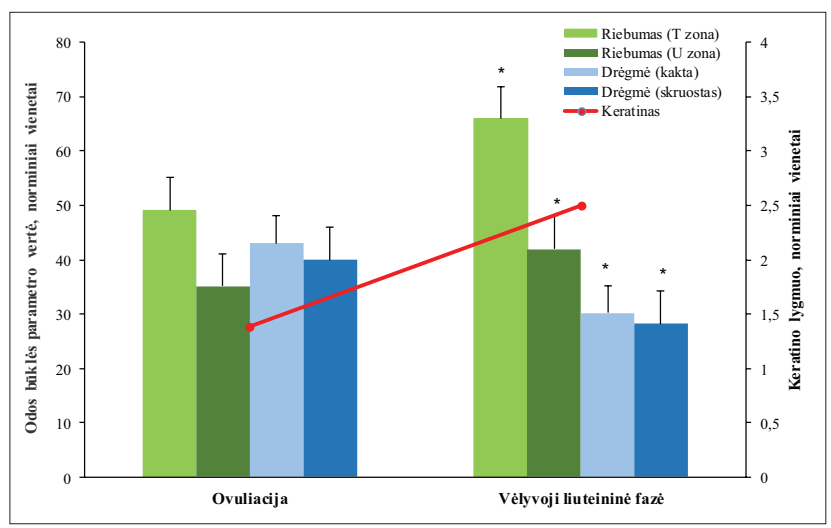

1 pav. Objektyvių odos būklès rodiklių vertinimas18-25 metų amžiaus grupèje $(\mathrm{N}=4)$.

${ }^{*} p<0,05$-ovuliacijos ir vélyvosios liuteininés fazés rodikliu skirtumas

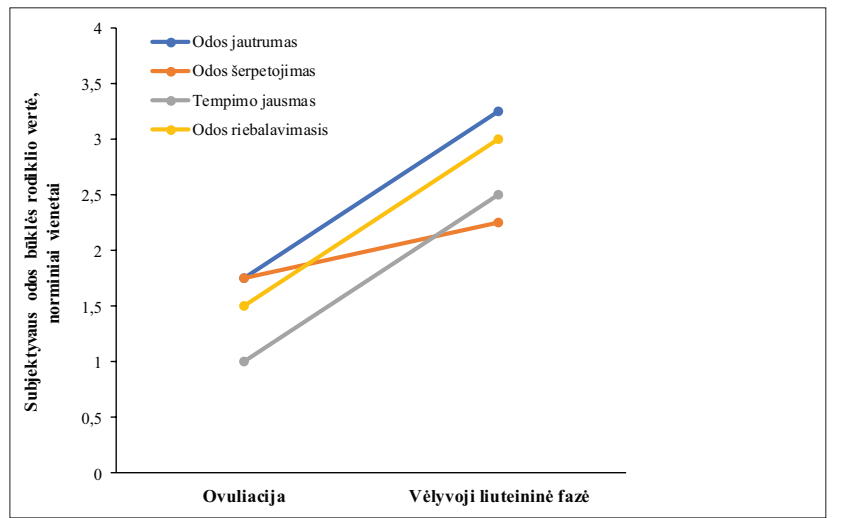

2 pav. Subjektyvių odos būklès rodiklių vertinimas, 18-25 metų amžiaus grupèje $(\mathrm{N}=4)$. zonose liuteininèje fazèje padidèjo $(\mathrm{p}<0,05)$. Mūsų gauti rezultatai prieštarauja mokslininko B. Dreno ir jo kolegu (2018) išvadoms, jog didesni pokyčiai liuteininèje fazèje turètų būti pastebimi U zonos riebumo rodmenyse. Lyginant drègmę ovuliacijos fazėje su liuteinine faze, drėgmė kaktoje bei skruostuose reikšmingai sumažèjo $(p<0,05)$, o keratino kiekis padidejo $(\mathrm{p}<0,05)$. Rezultatai atitiko A. Rzepecki ir kolegų [10] išvadą, kad ovuliacijos metu padidejjęs estrogenų kiekis sukelia teigiamus odos raginio sluoksnio būklès pokyčius (1 pav.).

Tyrimo dalyvès nurodè, jog artejjant menstruacijoms, subjektyvus odos tempimo pojūtis vidutiniškai buvo du kartus ryškesnis. Tai tiesiogiai siejama su sumažejusia odos drègme, susilpnejjusiomis apsauginėmis savybėmis ir suprastejjusia raginio sluoksnio būkle (2 pav.). Tyrimo dalyvès taip pat nurodè, jog jų odos jautrumas ženkliai padidejo vélyvojoje liuteininèje fazeje. Viena iš odos jautrumo priežasčiu - sutrikusi odos apsaugine funkcija, todèl net ịprastinès kosmetikos priemonès ir išoriniai dirgikliai tiriamujų odą veikè neịprastai, sukèlè nepageidaujamų pojūčių. Šio tyrimo rezultatai atitinka D. Falcone su kolegomis [5] atlikto tyrimo

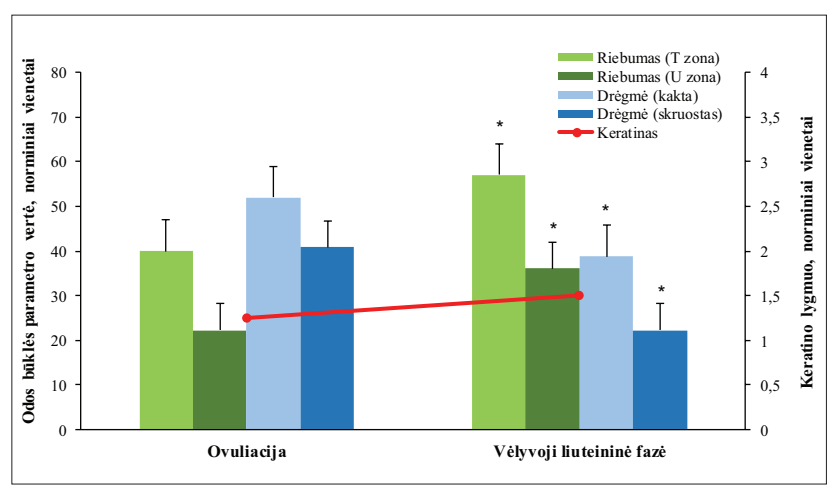

3 pav. Objektyvių odos būklès rodiklių vertinimas 34-45metų amžiaus grupeje $(\mathrm{N}=4)$.

$p<0,05$-ovuliacijos ir vélyvosios liuteininès fazès rodikliu skirtumas.

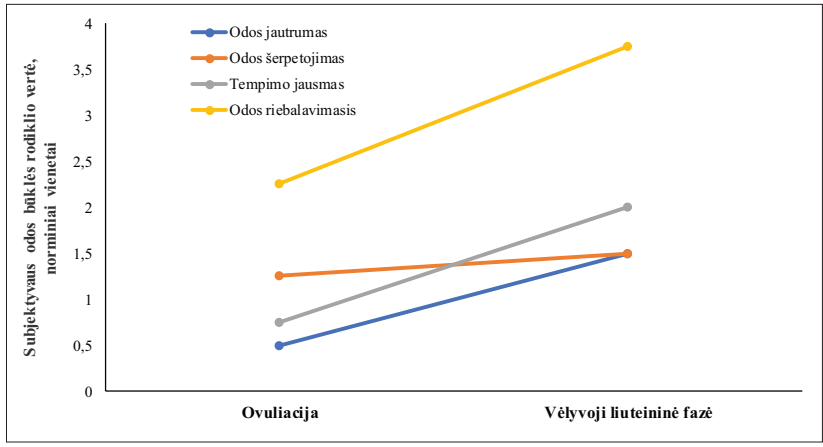

4 pav. Subjektyvių odos rodiklių vertinimas 34-45 metų amžiaus grupeje $(\mathrm{N}=4)$. 
rezultatus, kurio metu pastebimas bendras ne tik odos, bet ir viso moters organizmo jautrumo padidejjimas, reaguojant i i iprastinius aplinkos veiksnius.

Lyginant objektyvių odos būklès rodiklių pokyčius, pastebėti reikšmingi pokyčiai visų parametrų dinamikoje $(p<0,05)$ (3 pav.). Mažiausiai pakito keratino kiekis $(p<0,05)$, parodantis nedideli odos šerpetojimą (4 pav.).

Apibendrinant subjektyvius odos būklès rodiklių pokyčius 34-45 metų amžiaus grupèje, pastebimas tolygus visų tirtujų rodiklių padidejimas, artèjant menstruacijoms. Mažiausias pokytis pastebimas odos šerpetojimo dinamikoje (4 pav.).

\section{Išvados}

Visos tyrimo dalyvės teigè jautusios ženklius subjektyvių odos būklès rodiklių (jautrumo, šerpetojimo, tempimo, riebumo) pokyčius. Pastebėti reikšmingi objektyvių odos būklès rodiklių (drègmès, $\mathrm{T}$ ir $\mathrm{U}$ zonų riebumo, keratinizacijos) pokyčiai. Lyginant amžiaus grupėse, 34-45 metų moterys teigè jautusios daug stipresni odos jautrumą bei tempimą prieš menstruacijas, nei 18-25 metų moterys; 34-45 metų amžiaus grupejje nustatytas ženkliai didesnis U zonos padidèjimas nei 18-25 metų amžiaus grupejje.

\section{Literatūra}

1. Petkevičienė M. Vyresniưuų paauglių merginų (16-18 m.) menstruacijų patyrimas. Daktaro disertacija, LSMU, 2019.

2. Saint-Jean M, Khammari A, Seite S, Moyal D, Dreno B. Characteristics of premenstrual acne flare-up and benefits of a dermocosmetic treatment: a double-blind randomised trial. Eur J Dermatol2017;27(2):144-9. https://doi.org/10.1684/ejd.2016.2952

3. Irrera N, Pizzino G, D'Anna R, Vaccaro M, Arcoraci V, Squadrito F, Altavilla D, Bitto A. Dietary management of skin health: the role of genistein. Nutr2017;9(6):622. https://doi.org/10.3390/nu9060622

4. Yousef H, Sharma S. Anatomy, skin (integument), epidermis. StatPearls. Treasure Island (FL); StatPearls Publishing LLC.: St. Petersburg, FA, USA. 2018.

5. Falcone D, Richters RJ, Uzunbajakava NE, Van Erp PE, Van De Kerkhof PC. Sensitive skin and the influence of female hormone fluctuations: results from a cross-sectional digital survey in the Dutch population. Eur J Dermatol2017; 27(1):42-8. https://doi.org/10.1684/ejd.2016.2913

6. Farage MA, Neill S, MacLean AB. Physiological changes associated with the menstrual cycle: a review. Obstetrical \& Gynecological Survey 2009; 64(1):58-72.
https://doi.org/10.1097/OGX.0b013e3181932a37

7. Karčiauskienė J. Vaikų ir paauglių aknès epidemiologinè padètis Kauno mieste. Daktaro disertacija. Kaunas, 2015.

8. Gamble J. Puberty: early starters. Nature 2017;550(7674):S10. https://doi.org/10.1038/550S10a

9. Anusevičienė O.V., Cibas P., Lilienė L. Žmogaus anatomija ir fiziologija. Pasaulio lietuvių kultūros ir švietimo centras, 2002:131-2.

10. Rzepecki AK, Murase JE, Juran R, Fabi SG, McLellan BN. Estrogen-deficient skin: the role of topical therapy. Int JWomen's Dermatol2019;5(2):85-90.

https://doi.org/10.1016/j.ijwd.2019.01.001

\section{CHANGES OF SUBJECTIVE AND OBJECTIVE INDICATORS OF THE SKIN DURING WOMAN'S MENSTRUAL CYCLE \\ A.Vaitkūnaitė, Ž.Mickienė, J.Juozapavičienė, S.Čapkauskienè}

Keywords: subjective skin indicators, objective skin indicators, women, menstrual cycle.

\section{Summary}

Menstrual cycle - a series of cyclical physiological changes in the life of every healthy fertile woman. Fluctuations in hormone concentrations lead to a variety of noticeable changes in various tissues and organs. Amongst these changes are also skin changes, such as differences in skin sebum production, sensitivity, hydration, barrier function, color etc. As the life of a modern woman changes, following changes in the environment, lifestyle, nutrition and other factors, also menarche starting noticeably earlier, women tend to spend a larger part of their life experiencing menstruation and the functional changes that follow each cycle. As skin plays a large part in one's appearance and cyclical skin changes are regular and common, any cosmetologist aiming to reach professional success, has to have deep insight into this dynamic. So, research goal was to determine the variance in subjective and objective skin parameters during the menstrual cycle. Changes of the hormone level, especially hormone estrogen, during a woman's menstrual cycle showed a variety of changes of the skin indicators such as sensitivity, fatness, humidity, color, and more. The most pronounced increase in the 34-45 age group was skin fat changes in the U- zone. The subjective skin indicators also changed significantly in both age groups comparing ovulation and late luteal phases.

Correspondence to: sandrija.capkauskiene@go.kauko.lt

Gauta 2019-10-29 